The Geneva Papers on Risk and Insurance, 18 (No. 69, October 1993), 412-414

\title{
The Consumer Movements and the Impact on Insurance: An American Point of View
}

\author{
by Robert C. Winters*
}

I bring you greetings from The Prudential Insurance Company of America, not to be confused with our U.K. friends, Prudential Assurance, of which Sir Brian is such a distinguished representative.

Based as we are in Newark, New Jersey, it's the American perspective I hope to offer today... And, believe me, we have definite views on the subject of risk.

Some of our more famous Americans do, too. Among them, the late comedian Jack Benny, who once boasted about his extensive insurance coverages. "I don't want to tell you how much insurance I carry with The Prudential," he said, "but all I can say is: When I go, THEY go." Well, somehow our company has managed to survive Jack by nearly 20 years. But his humor was in one sense a bit prophetic.

In a disturbing trend, Americans are coming more and more to expect a risk-free existence - from cradle to grave.

In January 1989, the late Henry Fairlie wrote in The New Republic, "The idea that our individual lives and the nation's life can and should be risk-free has grown to be an obsession driven far and deep into American attitudes... As if the Declaration of Independence had been rewritten to include freedom from risk among the self-evident rights to life, liberty and the pursuit of happiness."

Surely this shift in attitude is familiar to some of our neighbors across the Atlantic, as well. But in America, particularly, it seems that people are seeking an existence in which every danger, unpleasantness or loss can be avoided. Or, if they can't altogether avoid them, they at least think these problems should be smoothed out by insurance or legislation. And, if all else fails, they can always file a lawsuit.

\footnotetext{
* Chairman and Chief Executive Officer, The Prudential Insurance Company of America, Newark. Paper presented at the 20th General Assembly of the Geneva Association. Vienna, June 7-8, 1993.
} 
The truth is, first of all, that we cannot eliminate risk, and second of all, that it is prohibitively expensive to try.

All over the world, when we look for the countries that have achieved the greatest improvements in health, safety and longevity, we find them to be the societies with risktaking, trial-and-error, entrepreneurial economies. They have out-produced, out-serviced and out-distributed economic systems dominated by central planning authorities. Those authorities begin by trying to provide their people with protection against all dangers. But, inevitably, they end up becoming excessively rigid, reactionary and cautious.

If the history of the past century has made anything crystal clear, it is that undue aversion to risk is the riskiest behavior of all.

A nation and its people cannot have the prospect of success without the prospect of failure. Nor hope without the risk of disappointment.

Still, the concept of absolute security as an "entitlement" prevails. The United States is perhaps unique among the major industrial nations in the degree to which it has eschewed broad government safety nets. But Americans are apparently not entirely comfortable with that decision, because they have sought to impose upon private insurers the burden of protecting all classes of Americans against myriad forms of harm.

Take our health-care situation, for example. Last year, health-care costs accounted for 14 percent of our Gross National Product, far more than that of any other country in the world.

Why are medical costs escalating? It traces in large measure to the desire of Americans to have access to the latest and best medical care available - irrespective of price. The high cost of our system is posing a serious threat to the whole country's economic health. Businesses are reducing their permanent work forces to avoid these costs, and millions of people are losing their health insurance protection.

Liability law is another arena where the desire for a painless life brings painful consequences. There are countless cases that illustrate where the United States chooses to answer to most of its problems: in the courtroom. One high school coach for an American football team in New Jersey was sued by the father of a player on the opposing team - for telling his players to hit harder. In another case, a woman sued the State of New York for \$ 1 million after being hit by a "dangerous object" on a Long-Island beach. It was a frisbee.

Ours is the most litigious country in the world. The cost to the American economy, because of our predilection for lawsuits, has been estimated at $\$ 300$ billions a year. What's more, the legal costs and other defensive measures of manufacturers, which are designed to avoid such expenditures, actually raise the cost of U.S. goods and services. They also inhibit the introduction of new ones.

The bottom line is that business is under pressure to earn strong returns without taking risks.

Insurers can - and should - take carefully weighed risks to increase returns. My own company has a long history of taking such risks to reap greater returns. Fortunately, our diversified portfolio allows us to withstand market fluctuations, while providing superior investment returns.

Unfortunately, though, the failures of a few large U.S. life insurers have led to unwarranted concern about the amount of risk in insurance company investment portfolios - 
and to restrictive legislation in many states. The fact is, less than 5 percent of the assets of U.S. life insurers is invested in below investment-grade bonds. Some are in publicly traded junk bonds, but many of these investments are private placement loans with protective covenants.

By imposing excessive restrictions on insurance company investment practices, legislators make it more difficult for many innovative new businesses to obtain the capital they need.

The challenges for the insurance industry are enormous: We need to educate consumers about the role insurance can reasonably play in protecting them from society's ills. We need to explain that we're in the business of protecting people from certain risks, not eliminating all risks. The latter might be an appealing concept, but from an economic standpoint, it's just not feasible.

Life is not risk-free. Nor is it the role of life or health or property and casualty insurers to make it that way. We need to remind and educate consumers about the appropriate balance between collective and individual responsibility.

A former American president, Herbert Hoover, knew the score pretty well all the way back in 1954: "Even if security from the cradle to the grave could eliminate the risks of life," he said, "it would be a dead hand on the creative spirit of our people." 